\title{
Kritičko vrednovanje dezinformacija u medijima unutar formalnog obrazovnog sustava u vrijeme pandemije koronavirusa
}

\author{
Lana Ciboci Perša \\ Edward Bernays Visoka škola, Zagreb, Hrvatska \\ e-mail: lana.ciboci@bernays.hr
}

\section{Tomislav Levak}

Akademija za umjetnost i kulturu u Osijeku, Odsjek za kulturu, medije $i$ menadžment, Hrvatska

e-mail:tomo.levak@gmail.com

\author{
Adrian Beljo \\ Edward Bernays Visoka škola, Zagreb, Hrvatska \\ e-mail:adrian.beljo@bernays.hr
}

SAŽETAK Od same pojave pandemije koronavirusa u medijima su se, a osobito na društvenim mrežama, osim pouzdanih i istinitih informacija pojavljivale i brojne dezinformacije o virusu, cijepljenju i njegovim posljedicama. Izloženost medijima u tom kriznom razdoblju ukazala je na važnost posjedovanja medijskih kompetencija s ciljem odabira kvalitetnih, pouzdanih i vjerodostojnih informacija. Naime, kritičko vrednovanje medijskih sadržaja postalo je ključno za pravilno razlikovanje istinitih i pouzdanih od nepouzdanih i nevjerodostojnih informacija. Za adekvatno stjecanje medijskih kompetencija važno je kvalitetno medijsko obrazovanje, koje se u Hrvatskoj, kada je u pitanju formalni obrazovni sustav, primarno provodi kroz nastavu $\mathrm{Hr}$ vatskoga jezika, ali i kroz različite međupredmetne teme (Ciboci, 2018.a). Vodeću ulogu u tom procesu imaju učitelji Hrvatskoga jezika i školski knjižničari (Ciboci, 2018.a; Kanižaj i Car, 2015.; Ciboci i Osmančević, 2015.). Da bismo mogli obrazovati mlađe generacije i potaknuti ih na kritičko promišljanje o medijima i medijskim sadržajima, oni koji ih tome podučavaju moraju biti medijski pismeni. Postavlja se pitanje koliko su sami provoditelji medijskog obrazovanja uspješni u prepoznavanju dezinformacija u medijima te koliko su često u posljednjih godinu dana stavljali naglasak u školama upravo na te teme, budući da su djeca jednako kao 
i odrasli izloženi brojnim dezinformacijama o koronavirusu, koje itekako mogu utjecati na njihove stavove i razmišljanja o cjelokupnoj pandemiji. U ovom je radu, metodom ankete, analizirano koliko školski knjižničari prepoznaju dezinformacije u medijima, kao i koliko je aktivnosti u posljednjih godinu dana u školama provedeno s ciljem educiranja učenika upravo o tom važnom problemu.

Ključne riječi: dezinformacije, kritičko vrednovanje, medijsko obrazovanje, medijska pismenost, koronavirus, knjižničari.

\section{Uvod}

Pandemija koronavirusa uzrokovala je velike promjene u ljudskim životima, kako privatnim tako i poslovnim. Zahvaljujući novim tehnologijama odrasli su počeli raditi, a djeca se školovati od kuće, što je pokazalo velike mogućnosti koje pružaju novi mediji i tehnologija. Osim na svakodnevni život, pandemija je utjecala i na navike medijskih korisnika, koji su više nego ikad vrijeme provodili uz različite medijske sadržaje (Statista, 2020.; Nielsen Company, 2020.), pri čemu su upravo mediji postali glavno sredstvo informiranja o novoj i nepoznatoj bolesti, i djece i odraslih (Statista, 2020.). Pritom je postalo ključno razlikovati provjerene, pouzdane i vjerodostojne medijske sadržaje od onih nepouzdanih, neprovjerenih i netočnih. Naime, prilikom izvještavanja o koronavirusu u medijima su, osobito na društvenim mrežama, objavljivane i brojne dezinformacije, što je više nego ikad ukazalo na važnost kritičkog promišljanja o medijima i posjedovanja medijskih kompetencija. Za adekvatno stjecanje medijskih kompetencija važno je kvalitetno medijsko obrazovanje, koje je nužno provoditi od najranije dobi, odnosno od prvog susreta djece s medijima i medijskim sadržajima (Ciboci, 2018.a; Ciboci, 2018.b), pri čemu pristup i oblik medijskog obrazovanja trebaju biti primjereni djetetovu uzrastu. Kvalitetno medijsko obrazovanje doprinosi stvaranju mudrih, odgovornih i medijski pismenih korisnika, što je u ovo vrijeme postalo neophodno te se $s$ razlogom medijska pismenost smatra jednim od ključnih oblika pismenosti u 21. stoljeću. Djeca već u osnovnoj školi trebaju steći medijske kompetencije koje su im nužne za odabir kvalitetnih medijskih sadržaja, osobito onih koji mogu biti ključni za njihovo shvaćanje okruženja i situacije u kojoj žive, kao što je pandemija koronavirusa.

U Hrvatskoj se medijsko obrazovanje primarno provodi kroz nastavu Hrvatskoga jezika, ali i kroz međupredmetne teme, kojima se osobito potiče razvijanje kritičkog promišljanja. Ključnu ulogu upravo u tom procesu imaju školski knjižničari. U ovom će se radu analizirati koliko su sami knjižničari u posljednjih godinu dana radili u školama na razvijanju medijskih kompetencija kod samih učenika, što je neophodno s obzirom na situaciju u kojoj se nalaze te razlikuju li se njihove aktivnosti s obzirom na starost i godine radnog staža. 


\section{Medijska pismenost i kritičko vrednovanje medijskih sadržaja}

Jednu od danas najkorištenijih definicija medijske pismenosti dala je Patricia Aufderheide još davne 1992. godine. Prema njoj, medijska pismenost podrazumijeva „sposobnost građana da pristupi, analizira i stvara informacije za postizanje specifičnih rezultata" (Aufderheide, 1992.: 6), dok je Europska komisija (2007.) medijsku pismenost definirala kao „sposobnost korištenja, razumijevanja, kritičkog evaluiranja i stvaranja medijskog sadržaja“" (Direktiva 2007/65/EZ).

Medijska je pismenost prije svega vještina analiziranja medijskih poruka i njihovog kritičkog sagledavanja (Scheibe i Rogow, 2012.; Silverblatt, 2001.) jer kod ljudi razvija svijest o utjecaju medijskih sadržaja na njihove stavove, razmišljanja i ponašanja te ih potiče na kritičko vrednovanje medijskih sadržaja, ali i na traženje većeg broja informacija iz različitih izvora (Potter, 2014.; Macedo i Steinberg, 2007.). Naime, krajnji cilj medijske pismenosti kritičko je razumijevanje, koje „uključuje sposobnost pretraživanja, odabira i analiziranja informacija i sadržaja, razumijevanje medijske okoline, ali i ekonomskog i društvenog razvoja unutar kojeg su ti sadržaji kreirani i podijeljeni drugima" (Pérez-Tornero i sur., 2010.: 1). Kritičko vrednovanje medijskih sadržaja važno je za informirano građanstvo (Danish Technological Institute i European Association for Viewers Interests, 2011.: 1; Bulger, 2012.: 84). Od medijski pismenih osoba zahtijeva se složena analiza medijskih sadržaja svih žanrova, a ne jednostavno dekodiranje riječi i doslovno shvaćanje tiskanih izvora (Burroughs i sur., 2009.: 156).

Za razvoj medijske pismenosti važno je pet ključnih elemenata kritičkog mišljenja (Scheibe i Rogow, 2012.: 25). Znatiželja i želja za postavljanjem pitanja jedan je od ključnih elemenata, prema kojem pojedinac odbacuje pojednostavljivanja i traži sve moguće dokaze prije donošenja zaključka (Scheibe i Rogow, 2012.: 25). Kontinuirani angažman u procesu ispitivanja drugi je element, koji pretpostavlja da kritični pojedinac kontinuirano analizira i evaluira informacije, kako one s kojima se slaže tako i one koje su mu sumnjive (Scheibe i Rogow, 2012.: 25). Osobe s razvijenim kritičkim mišljenjem izrazito su skeptične, jasno razlikuju činjenice od mišljenja te su vrlo otvorene i spremne mijenjati svoja razmišljanja na temelju dokaza (Scheibe i Rogow, 2012.: 25). Pri analizi medijske poruke važno je ispitati tko je kreirao određenu poruku i s kojom svrhom, tko je ciljana publika, tko je platio za tu poruku, tko bi mogao imati koristi od te poruke, koga bi ona na bilo koji način mogla oštetiti, zašto bi ta poruka mogla biti važna pojedincu, koje bi radnje morao poduzeti pojedinac pri odgovaranju na poruku (Scheibe i Rogow, 2012.: 39). Važno je istražiti i njezin sadržaj, koje se vrijednosti, ideje, informacije i stajališta njome prenose, koje su informacije izostavljene iz poruke, a koje bi mogle biti važne; koje su tehnike korištene, s kojim razlogom; kako različiti ljudi mogu na drugačiji način interpretirati poruku, na koji način pojedinac interpretira poruku i što može naučiti o samome sebi na temelju svoje reakcije ili interpretacije (Scheibe i Rogow, 2012.: 39). U trećem je dijelu vrlo važno analizirati kada je poruka nastala, na koji je način poslana publici te radi li se o činjenici, mišlje- 
nju ili nečem trećem; koliko je poruka pouzdana i na temelju čega pojedinac to misli te tko su izvori informacija, ideja i tvrdnji (Scheibe i Rogow, 2012.: 39). Navedena su pitanja ključna za prepoznavanje dezinformacija u medijima, kojima su medijski korisnici osobito izloženi u vrijeme pandemije.

\subsection{Pandemija koronavirusa i dezinformacije}

Pojam dezinformacije podrazumijeva namjerno stvoren lažni sadržaj koji se promovira s namjerom da se nekoga dovede u zabludu (Butcher, 2021.: 8). Uključuje izmišljen i namjerno manipuliran audio/vizualni sadržaj (Wardle, 2019.), koji se najčešće širi posredstvom medijskih platformi. U proteklih se nekoliko godina u znanstvenim i stručnim krugovima taj izraz uvriježio kao precizniji i prihvatljiviji termin za pojavu globalno poznatu pod kovanicom lažne vijesti, pa se u tom kontekstu i obliku koristi i u ovom radu. Dezinformacije se razlikuju od pojmova pogrešne i zlonamjerne informacije (Butcher, 2021.: 8). Pogrešne su informacije nenamjerne pogreške, poput netočnih potpisa ispod objavljenih fotografija, pogrešnoga datuma, statistika i prijevoda, ili ozbiljnoga prihvaćanja satiričnog sadržaja. Zlonamjerne informacije pojavljuju se u slučajevima namjernoga objavljivanja ili iskrivljavanja privatnih podataka u svrhu ostvarivanja neke koristi, primjerice kod ciljane izmjene konteksta ili vremena izvornoga događaja ili sadržaja (Wardle, 2019.). Bez obzira na razlike u načinima proizvodnje i motivacijama kreatora takvih sadržaja, u praksi sve tri navedene vrste predstavljaju prijetnju učinkovitoj i jasnoj komunikaciji (Butcher, 2021.).

Točnost $\mathrm{i}$ istinitost informacija vezanih uz aktualnu pandemiju koronavirusa kontinuirano prati i bilježi Faktograf.hr, trenutačno jedini hrvatski medij usmjeren primarno na činjeničnu provjeru informacija koje se pojavljuju u javnoj sferi. U razdoblju od početka veljače 2020. do početka ožujka 2021. godine Faktograf.hr otkrio je 353 informacije koje su objavljene ili prenesene i u hrvatskim medijima a za koje je naknadnom provjerom utvrđeno da su netočne ili neistinite (Faktograf.hr, 2021.). Te informacije obuhvaćaju različite teme i područja društva (zdravstvo, gospodarstvo, politika, sigurnosna pitanja, kultura, zabava i drugo), a većina ih se svrstava u kategoriju namjerno produciranih i proširenih dezinformacija. Od početka ožujka 2021. do početka srpnja 2021. godine na istom portalu izneseno je 67 razotkrivenih neistina (Faktograf.hr, 2021.), što je za oko $38,3 \%$ manje (u prosjeku 16,8 vijesti mjesečno) u odnosu na prethodnih 13 mjeseci (u prosjeku 27,2 vijesti mjesečno). No, i dalje su dezinformacije povezane $s$ koronavirusom uvelike prisutne $\mathrm{u}$ javnom prostoru, a ponajviše se diseminiraju pomoću društvenih mreža, komunikacijskih platformi i mobilnih aplikacija, kao što su WhatsApp i Viber (Faktograf.hr, 2021.). Među njima su i one koje imaju potencijalno ozbiljne posljedice, poput čestih neutemeljenih tvrdnji o štetnosti cjepiva. Zbog toga je Europska komisija pokrenula posebnu internetsku 
platformu „Suzbijanje dezinformacija o koronavirusu“" , na kojoj se redovito donose i ažuriraju korisne činjenice i dokumenti te se bilježe slučajevi dezinformacija o pandemiji, primjerice poput one da odašiljači za mrežu $5 \mathrm{G}$ služe za širenje koronavirusa (Europska komisija, 2021.). Najčešće objavljivane dezinformacije uključene su i u anketni upitnik koji je proveden za potrebe ovoga rada.

\section{Uloga nastavnika u medijskom obrazovanju}

Za uspješno medijsko opismenjivanje i prepoznavanje dezinformacija u medijima nužna je suradnja nastavnika, školskih djelatnika, medijskih stručnjaka i roditelja (Potter, 2005.: 321, prema Bilici, 2014.: 75). No, velik je problem što se ni roditelji ni nastavnici, koji djecu pripremaju za život i snalaženje u svim životnim okolnostima, ni sami ne znaju pravilno služiti medijima i kritički analizirati medijske poruke (Livingstone, Van Couvering i Thumim, 2005.; Ciboci i Osmančević, 2015.), te se taj nedostatak znanja itekako odražava na mlađim generacijama, koje sve više koriste medije, a da ih pritom nitko ne usmjerava i ne nadzire način na koji se medijima služe (Duerager i Livingstone, 2012., Ciboci i sur., 2020.). Upravo bi tu najvažniju ulogu trebale imati obrazovne institucije, koje trebaju biti vodiči učenicima u svakodnevnom korištenju medijskih sadržaja (Bilici, 2014.: 76). No, velik je problem što kreatori obrazovnih politika u mnogim državama ističu kako je školski sustav već pretrpan te da su predmeti poput Građanskog odgoja i Informatike važniji od medijskog obrazovanja (Buckingham, 2002.). Da bi nastavnici uvidjeli njezine prednosti i ugradili medijsku pismenost u svoju nastavu, prvo sami moraju postati svjesni temeljnih znanja i praksi iz tog područja (Scheibe, 2004.: 62). Važno im je pružiti podršku, prije svega u vidu njihova osobnog obrazovanja. Nastavnici sami tijekom svog obrazovanja moraju steći temeljna teorijska i praktična medijska znanja kako bi o njima mogli predavati učenicima, te je stoga nužno osigurati im treninge medijske pismenosti (Scheibe, 2004.: 61). Osim usavršavanja tijekom studija, nastavnicima je nužno omogućiti i cjeloživotno obrazovanje budući da je riječ o području koje se stalno razvija. Veliku pomoć nastavnicima u školama mogu pružiti i školski knjižničari (Baker, 2004).

\subsection{Formalno medijsko obrazovanje u hrvatskim školama i poticanje na kritičko vrednovanje medijskih sadržaja}

Važnost medijske pismenosti u potpunosti je prepoznato unutar hrvatskog formalnog obrazovnog sustava tek donošenjem Strategije obrazovanja, znanosti i tehnologije, koja je usvojena u Hrvatskome saboru u listopadu 2014. godine. Osim što se medijska pismenost navodi među ključnim kompetencijama, Strategija (NN 124/14) predviđa

\footnotetext{
1 Dostupno na: https://ec.europa.eu/info/live-work-travel-eu/coronavirus-response/fighting-disinformation/tackling-coronavirus-disinformation en.
} 
da je pri izradi kurikularnih dokumenata važno osigurati „uvođenje novih sadržaja kojima će se razvijati informacijska, financijska i medijska pismenost“.

U Hrvatskoj ne postoji zaseban predmet u školama koji se bavi medijskim obrazovanjem djece. Kao i u mnogim državama Europske unije (vidi Pérez-Tornero, 2014.; ANR TRANSLIT COST, 2014.), i u Hrvatskoj se medijsko obrazovanje djece ostvaruje primarno kroz materinski jezik, odnosno kroz domenu C. Kultura i mediji, koja je jedna od predmetnih sastavnica Hrvatskoga jezika. Medijski sadržaji prisutni su i u brojnim „izvannastavnim aktivnostima, na satu razrednika, kroz aktivnosti knjižničara, kroz stvaranje školskih časopisa te primjerice filmskih ili novinarskih družina" (Kanižaj i Car, 2015.: 20). Upravo knjižničari, uz učitelje razredne nastave i učitelje Hrvatskoga jezika, imaju ključnu ulogu u medijskom obrazovanju, osobito kroz domene međupredmetnih tema kao što su Vrednovanje informacija iz različitih izvora (tema Učiti kako učiti), Istraživanje i kritičko vrednovanje u digitalnome okružju (tema Uporaba informacijske i komunikacijske tehnologije), Vrednovanje informacija o zdravlju i zdravstvenim temama na internetu (tema Zdravlje) te Utjecaj medija i društvenih mreža na donošenje odluka mladih. Kritičko vrednovanje sadržaja iz medija i s društvenih mreža (tema Osobni i socijalni razvoj). Ključna je među njima, kada su knjižničari u pitanju, Uporaba informacijske i komunikacijske tehnologije, čiji su ciljevi „moralno i sigurno rabiti informacijsku i komunikacijsku tehnologiju učinkovito komunicirati i surađivati u digitalnome okružju informirano i kritički vrednovati i odabrati tehnologiju i služiti se tehnologijom primjerenom svrsi upravljati informacijama u digitalnome okružju stvarati i uređivati nove sadržaje te se kreativno izražavati s pomoću digitalnih medija" (Odluka o donošenju kurikuluma za međupredmetnu temu Uporaba informacijske i komunikacijske tehnologije za osnovne i srednje škole u Republici Hrvatskoj, NN 7/2019).

\section{Metodologija istraživanja}

Cilj ovoga rada bio je istražiti koliko sami knjižničari prepoznaju dezinformacije u medijima, s naglaskom na sadržaje o koronavirusu, te koliko je aktivnosti u posljednjih godinu dana u školama provedeno s ciljem educiranja učenika upravo o toj temi od samih knjižničara kao ključnih edukatora kritičkog vrednovanja informacija, pa tako i medijskih sadržaja. Specifični ciljevi istraživanja bili su utvrditi povezanost između stupnja povjerenja u medije s mišljenjem knjižničara o medijima koji najviše šire dezinformacije, istražiti smatraju li knjižničari $s$ više radnog staža da je djecu u školi nužno podučavati kako prepoznati dezinformacije u medijima, kao i koliku ulogu u cijelom tom procesu imaju sami knjižničari. $\mathrm{Na}$ temelju postavljenih ciljeva istraživanja proizašle su sljedeće hipoteze: 
H1: Kada su u pitanju informacije o koronavirusu, knjižničari stariji od 40 godina više vjeruju televiziji, dok knjižničari mlađi od 40 godina više vjeruju internetskim portalima.

H2: U odnosu na knjižničare s manje od deset godina staža, knjižničari s više od deset godina staža češće smatraju da djecu u školi treba podučavati kako prepoznati dezinformacije o koronavirusu koje se šire putem medija.

H3: Predavanje, radionice ili neku drugu aktivnost na temu dezinformacija u medijima i kritičkog vrednovanja medijskih sadržaja češće su u posljednjih godinu dana držali knjižničari s više od deset godina staža, nego oni s manje od deset godina.

H4: Knjižničari koji u svojim školama provode edukacije o kritičkom vrednovanju medijskih sadržaja i dezinformacijama u medijima češće smatraju da se u njihovoj školi učenike dovoljno podučava kritičkom vrednovanju medijskih sadržaja.

H5: Knjižničari koji se u potpunosti ili uglavnom ne slažu s tvrdnjom da ravnatelji u njihovoj školi kontinuirano potiču edukacije iz područja medijske pismenosti češće izražavaju neslaganje s tvrdnjom da se u njihovoj školi djecu dovoljno potiče na kritičko vrednovanje medijskih sadržaja.

Istraživanje je provedeno u veljači 2021. godine metodom internetske ankete, pri čemu su poveznicu za istraživanje dobili svi knjižničari koji sudjeluju na stručnim skupovima koje za njih organizira Agencija za odgoj i obrazovanje. U istraživanju je sudjelovalo 494 knjižničara, od kojih su $462(93,5 \%)$ osobe ženskog i $32(6,5 \%)$ osobe muškog spola. Prosječna dob ispitanika bila je 44,28 godina $(S D=9,44)$, pri čemu je prosječna dob muškaraca bila $40,78(S D=8,12)$, a žena 44,52 godine ( $S D$ = 9,48). $189(38,3 \%)$ sudionika imalo je manje od ili jednako 40 godina, a njih 305 $(61,74 \%)$ više od 40. Prosječni radni staž sudionika bio je 16,69 godina $(S D=9,60)$, pri čemu je 140 sudionika $(28,3 \%)$ imalo deset godina radnog staža ili manje, dok je $354(71,7 \%)$ sudionika imalo više od deset godina radnog staža. Većina je ispitanika, njih $333(67,4 \%)$, zaposleno u osnovnoj školi, $160(32,4 \%)$ ispitanika u srednjoj školi, dok je jedna osoba $(0,2 \%)$ zaposlena u gradskoj/mjesnoj knjižnici. U istraživanju su bili zastupljeni knjižničari iz svih hrvatskih županija, pri čemu najviše njih s područja Grada Zagreba (17,4\%), Primorsko-goranske (10,3\%) i Osječko-baranjske županije $(9,9 \%)$. Detaljan prikaz županija iz kojih su dolazili sudionici prikazan je u tablici 1 . 
Tablica 1.

Prikaz frekvencije i postotka sudionika iz pojedine županije $(\mathrm{N}=494)$

\begin{tabular}{|l|c|c|}
\hline Županija & $\mathbf{F}$ & $\%$ \\
\hline Bjelovarsko-bilogorska & 19 & 3,85 \\
\hline Brodsko-posavska & 25 & 5,06 \\
\hline Dubrovačko-neretvanska & 10 & 2,02 \\
\hline Grad Zagreb & 86 & 17,41 \\
\hline Istarska & 27 & 5,47 \\
\hline Karlovačka & 21 & 4,25 \\
\hline Koprivničko-križevačka & 11 & 2,23 \\
\hline Krapinsko-zagorska & 18 & 3,64 \\
\hline Ličko-senjska & 5 & 1,01 \\
\hline Međimurska & 17 & 3,44 \\
\hline Osječko-baranjska & 49 & 9,92 \\
\hline Požě̌ko-slavonska & 17 & 3,44 \\
\hline Primorsko-goranska & 51 & 10,32 \\
\hline Sisačko-moslavačka & 20 & 4,05 \\
\hline Splitsko-dalmatinska & 18 & 3,64 \\
\hline Šibensko-kninska & 7 & 1,42 \\
\hline Varaždinska & 19 & 3,85 \\
\hline Virovitičko-podravska & 25 & 3,64 \\
\hline Vukovarsko-srijemska & 18,05 \\
\hline Zadarska & 7,23 \\
\hline Zagrebačka & 25 & 5,06 \\
\hline
\end{tabular}

\subsection{Rezultati istraživanja}

\subsubsection{Informiranje i povjerenje u medije}

Internetski portali i internetska izdanja novina većini su knjižničara $(50,8 \%)$ glavni izvor informiranja o pandemiji koronavirusa. $\mathrm{Na}$ drugom se mjestu nalazi televizija $(30,8 \%)$, a na trećem društvene mreže $(9,9 \%)$. Tek su se rijetki o pandemiji informirali kroz radio $(3,6 \%)$, tiskane medije $(1,4 \%)$ i komunikacijske platforme (Viber, WhatsApp i slično) $(1,8 \%)$. Unatoč tome, najveći stupanj povjerenja u medije, kada su u pitanju informacije o koronavirusu, većina je knjižničara pokazala prema radiju i televiziji, a najmanji prema društvenim mrežama i internetskim portalima (tablica 2). 
Tablica 2.

Stupanj povjerenja u medije kada su u pitanju informacije o koronavirusu $(\mathrm{N}=494)$

\begin{tabular}{|l|c|c|c|c|c|c|c|c|c|c|}
\hline & \multicolumn{2}{|c|}{$\begin{array}{c}\text { U potpunosti } \\
\text { im ne vjerujem }\end{array}$} & \multicolumn{2}{|c|}{$\begin{array}{c}\text { Uglavnom im } \\
\text { ne vjerujem }\end{array}$} & \multicolumn{2}{|c|}{$\begin{array}{c}\text { Niti im } \\
\text { vjerujem niti } \\
\text { im ne vjerujem }\end{array}$} & \multicolumn{2}{|c|}{$\begin{array}{c}\text { Uglavnom im } \\
\text { vjerujem }\end{array}$} & \multicolumn{2}{|c|}{$\begin{array}{c}\text { U potpunosti } \\
\text { im vjerujem }\end{array}$} \\
\hline & $\mathrm{N}$ & $\%$ & $\mathrm{~N}$ & $\%$ & $\mathrm{~N}$ & $\%$ & $\mathrm{~N}$ & $\%$ & $\mathrm{~N}$ & $\%$ \\
\hline Tiskani mediji & 20 & 4,1 & 51 & 10,3 & 275 & 55,7 & 144 & 29,2 & 4 & 0,7 \\
\hline Radio & 17 & 3,4 & 30 & 6,1 & 221 & 44,7 & 213 & 43,1 & 13 & 2,6 \\
\hline Televizija & 20 & 4,1 & 45 & 9,1 & 217 & 43,9 & 202 & 40,9 & 10 & 2,0 \\
\hline Internetski portali & 18 & 3,6 & 102 & 20,7 & 278 & 56,3 & 96 & 19,4 & 0 & 0 \\
\hline Društvene mreže & 67 & 13,6 & 181 & 36,6 & 217 & 43,9 & 29 & 5,9 & 0 & 0 \\
\hline
\end{tabular}

Istraživanjem je analizirano i vjeruju li knjižničari stariji od 40 godina više televiziji, a oni mlađi od 40 godina internetskim portalima (hipoteza 1). Kako bi se ispitalo hipotezu, primijenjen je mješoviti model analize varijance u koju je kategorija dobi sudionika (manje - više od 40 godina) uvrštena kao učinak između sudionika, a tip medija (internetski portali - televizija) uvršten kao učinak unutar sudionika. U nastavku su prikazani deskriptivni podaci za sve četiri kategorije nezavisnih varijabli.

Tablica 3.

Stupanj povjerenja u internetske portale i televiziju s obzirom na dob ispitanika

\begin{tabular}{|l|c|c|c|c|}
\hline Dob & Medij & $\mathbf{n}^{*}$ & $\mathbf{M}^{* *}$ & $\mathbf{S D}^{* * *}$ \\
\hline Manje od 40 & Internetski portali & 189 & 2,87 & 0,73 \\
\hline Manje od 40 & Televizija & 189 & 3,18 & 0,88 \\
\hline Više od 40 & Internetski portali & 305 & 2,94 & 0,74 \\
\hline Više od 40 & Televizija & 305 & 3,34 & 0,77 \\
\hline
\end{tabular}

${ }^{*} \mathrm{n}$ - broj sudionika u pojedinoj kategoriji, $\mathrm{M}^{* *}$ - aritmetička sredina, $\mathrm{SD}^{* * *}$ - standardna devijacija

Nadalje, pomoću Levenovog testa provjerena je homogenost varijanci dviju varijabli koje su ispitane kao učinak unutar ispitanika, s obzirom na nezavisnu varijablu između ispitanika. Pokazalo se da rezultati obiju skupina sudionika imaju podjednake varijance i prilikom procjenjivanja internetskih portala $(\mathrm{F}(1,492)=0.01, \mathrm{p}=.93) \mathrm{i}$ televizije $(\mathrm{F}(1,492)=0,05, \mathrm{p}=, 82)$ kao medija kojima vjeruju. Nadalje, preduvjet homogenosti kovarijanci također se pokazao zadovoljenim (Box $M=1,48, p=, 22$ ), te je provedena analiza varijance, čiji su rezultati prikazani u tablici 4. 
Tablica 4.

Stupanj povjerenja u medije - analiza varijance

\begin{tabular}{|l|c|c|c|c|}
\hline Učinak & SS $_{\text {uc̈inak }}$ & SS $_{\text {pogreška }}$ & $\mathbf{F}$ & $\mathbf{p}$ \\
\hline Dob & 1 & 492 & 3,523 &, 061 \\
\hline Medij & 1 & 492 & 80,47 & $<, 001$ \\
\hline Dob*Medij & 1 & 492 & 1,31 &, 25 \\
\hline
\end{tabular}

Rezultati upućuju na to da ne postoji značajna razlika među sudionicima različite dobi $(\mathrm{F}(1,492)=3,52, \mathrm{p}=, 061) \mathrm{u}$ tome koliko vjeruju televiziji ili internetskim portalima. Nadalje, utvrđen je statistički značajan učinak tipa medija $(\mathrm{F}(1,492)=80,47$, $\mathrm{p}<$ ,001), što upućuje na to da sudionici ne vjeruju podjednako u oba ispitana medija. Pokazalo se da sudionici više vjeruju televiziji $(M=3,28, S D=0,82)$ nego internetskim portalima $(M=2,92, S D=0,74)$. Nadalje, nije utvrđen interakcijski učinak dobi i medija $(F(1,492)=1,32, p=, 25)$, što upućuje na to da su procjene o vjerovanju u dva tipa medija podjednake za obje dobne skupine sudionika. Drugim riječima, i mlađi i stariji od 40 godina više vjeruju televiziji nego internetskim portalima.

\subsubsection{Dezinformacije u medijima}

Društvene mreže najveći broj ispitanika, njih 63,6\%, ističe kao medij putem kojeg se širi najveći broj dezinformacija o koronavirusu. Da su to internetski portali i internetska izdanja novina smatra $15,6 \%$ knjižničara, a njih $13,6 \%$ ističe da su to komunikacijske platforme za dopisivanje, $4 \%$ knjižničara navelo je televiziju, $2 \%$ tiskane novine, dok je 1,2\% ispitanika navelo sve medije podjednako.

Ključnim za prepoznavanje dezinformacija u medijima knjižničari su naveli nekoliko ključnih stvari: provjeru informacija kroz različite izvore, educiranost i razvoj kritičkog mišljenja, odnosno čitanje teksta $s$ razumijevanjem te pouzdanost i vjerodostojnost autora članka i medija koji je objavio informaciju. Tako je jedan od ispitanika istaknuo sljedeće: „Ključno je prepoznati od koga, tj. koje osobe ili organizacije dolaze informacije o koronavirusu i s kojim ciljem. Važno je biti dovoljno obrazovan kako bi znali ima li znanstvenu podlogu iznesena informacija... Važno je informirati se o koronavirusu od zdravstvenih stručnjaka i znanstvenika koji se bave tim područjem. Potrebno je analizirati i kritički vrednovati informacije dobivene putem različitih medija i društvenih mreža." Drugi je pak istaknuo da kod medijskih korisnika sumnju trebaju potaknuti sve „rečenične konstrukcije poput: Istraživanja su pokazala... (a u kojima se ne navodi gdje se provodilo istraživanje, tko ga je provodio i sl.)“.

Kad su u pitanju dezinformacije o koronavirusu, istraživanje je pokazalo da je većina knjižničara čula za većinu njih. Najveći broj ispitanika čuo je za dezinformacije kao što 
su „Koronavirus je umjetno stvoren u laboratoriju i namjerno pušten u javnost.“, „Koronavirus je opasan koliko i obična gripa.“, „Cjepivo se koristi za čipiranje ljudi.“ te „U prevenciji zaraze koronavirusom može pomoći redovito ispiranje nosa fiziološkom otopinom.". Za neke od dezinformacija koje su kružile u medijima čuo je tek manji broj knjižničara. Primjerice, za tvrdnju da se koronavirus može prenijeti ugrizom komaraca čulo je tek $13 \%$ ispitanika, da se koronavirus s osobe na osobu može prenijeti putem mobilnih 5G mreža čulo je 43,2\% ispitanika, da djeca najviše šire koronavirus čulo je 45,8\% ispitanika, a da češnjak i vitamin C liječe koronavirus čulo je njih 47,5\%. Iako su sve navedene tvrdnje dokazano dezinformacije i kao takve su često bile istaknute i u samim medijima, dio njih jedan velik dio knjižničara ne smatra dezinformacijama. Tvrdnju prema kojoj u prevenciji zaraze koronavirusom može pomoći redovito ispiranje nosa fiziološkom otopinom dezinformacijom smatra 55,2\% ispitanika, dok njih 58\% smatra da je dezinformacija tvrdnja da je koronavirus umjetno stvoren u laboratoriju i namjerno pušten u javnost. Iako je za obje tvrdnje čula većina ispitanika, puno je manji broj njih čuo da je riječ o dezinformacijama, što pokazuje da demanti određene informacije na kraju dođe ipak do puno manjeg broja medijskih korisnika.

Tablica 5.

Dezinformacije o koronavirusu u medijima $(\mathrm{N}=494)$

\begin{tabular}{|c|c|c|}
\hline $\begin{array}{l}\text { Postotak ispitanika koji su } \\
\text { za navedenu tvrdnju čuli u } \\
\text { medijima }\end{array}$ & $\begin{array}{l}\text { Postotak ispitanika } \\
\text { koji navedenu } \\
\text { tvrdnju smatraju } \\
\text { dezinformacijom } \\
\end{array}$ & Tvrdnja o koronavirusu \\
\hline $43,2 \%$ & $97,6 \%$ & $\begin{array}{l}\text { Koronavirus se s osobe na osobu može prenijeti putem } \\
\text { mobilnih } 5 \mathrm{G} \text { mreža. }\end{array}$ \\
\hline $74,5 \%$ & $92,9 \%$ & Cjepivo se koristi za čipiranje ljudi. \\
\hline $61,5 \%$ & $55,2 \%$ & $\begin{array}{l}\text { U prevenciji zaraze koronavirusom može pomoći } \\
\text { redovito ispiranje nosa fiziološkom otopinom. }\end{array}$ \\
\hline $89,4 \%$ & $58,0 \%$ & $\begin{array}{l}\text { Koronavirus je umjetno stvoren u laboratoriju i } \\
\text { namjerno pušten u javnost. }\end{array}$ \\
\hline $79,0 \%$ & $75,8 \%$ & Koronavirus je opasan koliko i obična gripa. \\
\hline $54,0 \%$ & $77,8 \%$ & $\begin{array}{l}\text { Koronavirus je stvoreno biooružje u međusobnoj borbi } \\
\text { svjetskih supersila. }\end{array}$ \\
\hline $59,7 \%$ & $75,6 \%$ & $\begin{array}{l}\text { Koronavirus je stvoren u svrhu smanjenja svjetske } \\
\text { populacije. }\end{array}$ \\
\hline $47,5 \%$ & $82,5 \%$ & Češnjak i vitamin C liječe koronavirus. \\
\hline $67,6 \%$ & $91,9 \%$ & Koronavirus uopće ne postoji. \\
\hline $45,8 \%$ & $73,7 \%$ & Djeca najviše šire koronavirus. \\
\hline $13,0 \%$ & $90,8 \%$ & Koronavirus se može prenijeti ugrizom komaraca. \\
\hline $51,3 \%$ & $68,2 \%$ & $\begin{array}{l}\text { Polovica liječnika u Hrvatskoj odbila je cijepljenje } \\
\text { protiv koronavirusa. }\end{array}$ \\
\hline
\end{tabular}




\subsubsection{Obrazovanje o dezinformacijama u školama}

Trećim je dijelom istraživanja analizirano koliko se djecu u školi podučava kritičkom vrednovanju i prepoznavanju dezinformacija u medijima. U tablici 5 prikazane su frekvencije sudionika s manje ili više od deset godina staža koji smatraju odnosno ne smatraju da djecu u školi treba podučavati kako prepoznati dezinformacije o koronavirusu koje se šire putem medija (hipoteza 2). Ispod frekvencije prikazan je postotak sudionika unutar svake kategorije staža koji su odgovorili na pitanje. Među ispitanicima koji imaju manje od deset godina staža $(\mathrm{N}=140)$, tek je njih troje $(2,1 \%)$ odgovorilo da ne smatraju da u školi djecu treba podučavati kako prepoznati dezinformacije o koronavirusu koje se šire putem medija.

Tablica 6.

Podučavanje u školi o dezinformacijama o koronavirusu koje se šire putem medija

\begin{tabular}{|l|c|c|c|}
\hline Staž & Ne smatram & Smatram & Ukupno \\
\hline \multirow{2}{*}{ Manje od 10 } & 3 & 137 & 140 \\
\cline { 2 - 4 } & $2,1 \%$ & $97,9 \%$ & $100 \%$ \\
\hline \multirow{2}{*}{ Više od 10 } & 12 & 342 & 354 \\
\hline \multirow{2}{*}{ Ukupno } & $3,4 \%$ & $96,6 \%$ & $100 \%$ \\
\cline { 2 - 4 } & 15 & 479 & 494 \\
\hline
\end{tabular}

Hipoteza 2 testirana je pomoću hi-kvadrat testa. Utvrđeno je da se sudionici s manje od deset i oni $s$ više od deset godina staža ne razlikuju statistički značajno prema tome smatraju li da djecu u školi treba podučavati kako prepoznati dezinformacije o koronavirusu koje se šire putem medija $\left(\chi^{2}(1)=0,191, p=0,573\right)$. Većina $(97 \%)$ sudionika smatra da učenike treba učiti kako da prepoznaju dezinformacije. Unatoč tome, tek $46,8 \%$ knjižničara ističe da je u posljednjih godinu dana u njihovoj školi održano predavanje, radionica ili neka druga aktivnost upravo na temu dezinformacija, dok njih $52,8 \%$ ističe da je takva aktivnost održana na temu kritičkog vrednovanja medijskih sadržaja (tablica 7).

Tablica 7.

Održavanje predavanja, radionice ili neke druge aktivnosti u posljednjih godinu dana

\begin{tabular}{|l|c|c|c|c|}
\hline & \multicolumn{2}{|c|}{ Da } & \multicolumn{2}{c|}{ Ne } \\
\hline & F & $\%$ & F & $\%$ \\
\hline Dezinformacije u medijima & 231 & 46,8 & 263 & 53,2 \\
\hline Kritičko vrednovanje medijskih sadržaja & 261 & 52,8 & 233 & 47,2 \\
\hline Senzacionalistički medijski sadržaji & 108 & 21,9 & 386 & 78,1 \\
\hline Medijsko izvještavanje o koronavirusu & 96 & 19,4 & 398 & 80,6 \\
\hline
\end{tabular}


Navedene su aktivnosti u najvećem broju slučajeva održali sami knjižničari $(63,1 \%)$, potom pedagozi i psiholozi $(39,5 \%)$, učitelji Informatike (22\%), učitelji Hrvatskoga jezika $(14,2 \%)$ i razrednici $(3,6 \%) .{ }^{2}$ Takve se aktivnosti puno češće održavaju za učenike predmetne nego razredne nastave. Naime, sudionici tih radionica najčešće su bili učenici predmetne nastave $(50,8 \%)$, potom stručni suradnici $(45 \%)$ i učitelji $(34,5 \%)$, učenici u srednjoj školi $(30,4 \%)$, učenici razredne nastave $(26,2 \%)$ te roditelji $(6,1 \%){ }^{3}$

Najvažniju ulogu u školi u educiranju o dezinformacijama o koronavirusu ${ }^{4}$ koje se šire putem medija, prema mišljenju $85,6 \%$ knjižničara, imaju svi učitelji podjednako. Tek 48,2\% knjižničara smatra da najvažniju ulogu u tom procesu imaju upravo oni, iako je kritičko vrednovanje informacija dio kurikuluma međupredmetnih tema, dok njih $45,7 \%$ ističe da najvažniju ulogu u tom procesu imaju pedagozi i psiholozi, iako to prema službenom kurikulumu nije njihova zadaća. $U$ ovom je istraživanju tek 43,5\% knjižničara priznalo da su sami u posljednjih godinu dana održali predavanje, radionicu ili neku druga aktivnost na tu temu. Iako bi uz knjižničare najvažniju ulogu u medijskom obrazovanju trebali imati učitelji Hrvatskoga jezika, njih je navelo tek $11,3 \%$ ispitanika, dok je 19,6\% navelo učitelje Informatike.

Upravo je uz održavanje takvih aktivnosti bila vezana i hipoteza 3, prema kojoj su predavanje, radionice ili neku drugu aktivnost na temu dezinformacija u medijima i kritičkog vrednovanja medijskih sadržaja češće u posljednjih godinu dana držali knjižničari $s$ više od deset godina staža nego oni s manje od deset (tablica 8). Knjižničari s manje od deset is više od deset godina staža ne razlikuju se statistički značajno u tome koliko često održavaju aktivnosti na temu dezinformacija u medijima $\left(\chi^{2}(1)=0,000, \mathrm{p}\right.$ $=1,000)$. Na razini cijelog uzorka, knjižničari su podjednako često održavali $(53,2 \%)$ i nisu održavali $(46,8 \%)$ aktivnosti na tu temu.

Tablica 8.

Održavanje predavanja, radionice ili neka druge aktivnosti vezane uz dezinformacije u medijima u posljednjih godinu dana s obzirom na godine staža

\begin{tabular}{|l|c|c|c|}
\hline Staž & Da & Ne & Ukupno \\
\hline \multirow{2}{*}{ Manje od 10 } & 65 & 75 & 140 \\
\cline { 2 - 4 } & $46,4 \%$ & $53,6 \%$ & $100 \%$ \\
\hline \multirow{2}{*}{ Više od 10 } & 166 & 188 & 354 \\
\hline \multirow{2}{*}{ Ukupno } & $46,9 \%$ & $53,1 \%$ & $100 \%$ \\
\cline { 2 - 4 } & 231 & 263 & 494 \\
\hline
\end{tabular}

2 Dana je mogućnost višestrukih odgovora.

3 Dana je mogućnost višestrukih odgovora.

${ }^{4}$ Dana je mogućnost višestrukih odgovora. 
U tablici 9 prikazane su frekvencije knjižničara s manje odnosno s više od deset godina staža koji jesu odnosno koji nisu u proteklih godinu dana provodili aktivnosti vezane uz kritičko vrednovanje medijskih sadržaja. Knjižničari s manje od deset i oni s više od deset godina staža ne razlikuju se statistički značajno u tome koliko često održavaju aktivnosti na temu kritičkog vrednovanja medijskog sadržaja $\left(\chi^{2}(1)=3,585, \mathrm{p}=\right.$ $0,058)$. Na razini cijelog uzorka, knjižničari su podjednako često održavali $(52,8 \%)$ i nisu održavali $(47,2 \%)$ aktivnosti na tu temu.

Tablica 9.

Održavanje predavanja, radionice ili neke druge aktivnosti vezane uz kritičko vrednovanje medijskih sadržaja u posljednjih godinu dana s obzirom na godine staža

\begin{tabular}{|l|c|c|c|}
\hline Staž & Da & Ne & Ukupno \\
\hline \multirow{2}{*}{ Manje od 10 } & 64 & 76 & 140 \\
\cline { 2 - 4 } & $45,7 \%$ & $54,3 \%$ & $100 \%$ \\
\hline \multirow{2}{*}{ Više od 10 } & 197 & 157 & 354 \\
\hline \multirow{2}{*}{ Ukupno } & $55,6 \%$ & $44,4 \%$ & $100 \%$ \\
\cline { 2 - 4 } & 261 & 233 & 494 \\
\hline
\end{tabular}

Istraživanjem je analizirano i smatraju li knjižničari koji provode edukacije o dezinformacijama u medijima više da se u njihovoj školi dovoljno podučava kritičkom vrednovanju medijskih sadržaja u odnosu na knjižničare koji nisu provodili takve edukacije (hipoteza 4). Levenovim testom homogenosti varijance utvrđeno je da se varijance odgovora dviju skupina knjižničara statistički ne razlikuju značajno $(F(1,492)=0,97$, $\mathrm{p}=, 33)$, te su podaci analizirani t-testom za nezavisne uzorke. Dokazano je da knjižničari koji su provodili edukacije $(M=2,98)$, u odnosu na one koji nisu $(M=2,39)$, statistički značajno više smatraju da se u njihovoj školi dovoljno podučava kritičkom vrednovanju medijskih sadržaja $(\mathrm{t}(492)=6,46, \mathrm{p}<0,001)$.

U radu je analizirano i smatraju li knjižničari koji provode edukacije o kritičkom vrednovanju sadržaja više da se u njihovoj školi dovoljno podučava kritičkom vrednovanju medijskih sadržaja u odnosu na knjižničare koji nisu provodili takve edukacije. Levenovim testom homogenosti varijance utvrđeno je da se varijance odgovora dviju skupina knjižničara ne razlikuju statistički značajno $(F(1,492)=1,93, p=, 17)$, te su podaci analizirani t-testom za nezavisne uzorke. Pokazano je da knjižničari koji su provodili edukacije $(M=2,91)$, u odnosu na one koji nisu $(M=2,39)$, statistički značajno više smatraju da se u njihovoj školi dovoljno podučava kritičkom vrednovanju medijskih sadržaja $(\mathrm{t}(492)=5,61, \mathrm{p}<, 001)$.

Istraživanjem je analizirano razlikuju li se knjižničari koji se u potpunosti ili uglavnom ne slažu s tvrdnjom da ravnatelji u njihovim školama kontinuirano potiču edukacije 
iz područja medijske pismenosti od onih koji se $s$ tom tvrdnjom djelomično ili u potpunosti slažu ili se niti slažu niti ne slažu (hipoteza 5). Levenov test homogenosti varijance pokazao je da se varijance tih dviju skupina značajno razlikuju $(F(1,492)$ $=4,17, \mathrm{p}=, 04)$, te su podaci analizirani Welchovim t-testom kako bi se napravila korekcija za nejednaku varijancu među skupinama. Pokazano je da knjižničari koji smatraju da ravnatelji ne potiču dovoljno edukacije iz područja medijske pismenosti $(\mathrm{M}=1,95), \mathrm{u}$ odnosu na one koji smatraju da ravnatelji potiču dovoljno edukacije iz medijske pismenosti $(M=2,95)$, statistički značajno manje smatraju da se u njihovoj školi djecu dovoljno potiče na kritičko vrednovanje medijskih sadržaja $(\mathrm{t}(289,06)=$ $11,02, \mathrm{p}<, 001)$.

\section{Zaključak}

Medijsko obrazovanje ključno je za stvaranje mudrih i odgovornih medijskih korisnika. Međutim, ono što su pokazali i rezultati ovog istraživanja je da unutar formalnog obrazovnog sustava, koji ima najvažniju ulogu u prijenosu i izgradnji medijskih kompetencija kod najmlađih generacija, nedostaje sustavna edukacija o medijima čak i u vrijeme pandemije koronavirusa, koju su mnogi, zbog brojnih dezinformacija koje su se pojavile u različitim vrstama medije, nazvali infodemijom. Uz učitelje Hrvatskoga jezika, ključnu ulogu u hrvatskim školama, kad je u pitanju medijsko opismenjavanje i podučavanje kritičkom vrednovanju medijskih sadržaja, imaju stručni suradnici knjižničari. No, ono što su pokazali rezultati ovoga istraživanja je da čak ni oni sami ne prepoznaju svoju važnu ulogu unutar tog procesa i pripisuju je stručnim suradnicima pedagozima i psiholozima, kojima to nije primarna zadaća i djelatnost, te da sami nedovoljno pozornosti posvećuju aktivnostima poput predavanja i radionica kojima bi se kod djece razvijale potrebne medijske kompetencije za snalaženje u medijskom prostoru, osobito novim medijima i društvenim mrežama, na kojim se često mogu naći i dezinformacije. Da bi i sama djeca znala prepoznati i razlikovati istinite i vjerodostojne izvore informacija i razlikovati ih od nepouzdanih, ključne su vještine kritičkog razmišljanja i vrednovanja informacija. Ovo je istraživanje pokazalo da tek svaki četvrti knjižničar smatra da se u njihovoj školi djecu dovoljno podučava kritičkom vrednovanju medijskih sadržaja. Da bi se to promijenilo i da bismo konačno stvorili generacije medijski pismenih korisnika koji s kritičkim razumijevanjem koriste medije, a ne stvarali generacije korisnika čiji je stupanj povjerenja u informacije do kojih dođu na društvenim mrežama, različitim videoplatformama i platformama za dopisivanje među najvišima u Europi (Eurobarometar, 2018.), važno je mijenjati i medijske i obrazovne politike, u kojima će se puno veći naglasak staviti na razvoj medijski pismenih korisnika. Promjene obrazovnih politika važne su i kako bi se konačno educirali stručnjaci u tom području, koji će svoje znanje i vještine prenositi mlađim generacijama jer ono što se sada pokazuje je da oni koji u tome imaju ključnu ulogu, učitelji Hrvatskoga jezika te sami knjižničari, kao što su pokazali rezultati ovoga istraživanja, ne prihvaćaju tu važnu ulogu i odgovornost i prebacuju je na druge 
dionike. Da bismo konačno napravili pomak, trebamo se ugledati na druge države, poput skandinavskih, i educirati stručnjake koji će unutar posebnih predmeta, bilo obveznih ili izbornih, razvijati medijske kompetencije već kod najmlađih generacija jer samo ćemo tako stvoriti mudre i odgovorne članove društva.

\section{Literatura}

1. ANR TRANSLIT COST (2014). Transforming Audiences/transforming Societies izvjeśća - Media and information literacy policies in Europe. http://ppemi.enscachan.fr/doku.php. (Pregledano 7. travnja 2015.)

2. Aufderheide, P. (1992). Media Literacy. A Report of the National Leadership Conference on Media Literacy. Queenstown, Maryland: The Aspen Institute.

3. Baker, F. (2004). Celebrating National Literacy Month: Media Literacy. School Library Media Activities Monthly, 21 (1): 50-51.

4. Bilici, E. I. (2014). Competition vs. Collaboration: A Study on Promoting Children's, Parental and Teachers' Collaborative Roles in Twenty First Century Digital and Media Literacy Education. Medijska istraživanja, 20 (2): 68-84.

5. Buckingham, D. (2002). Children and Media. Pariz: Unesco.

6. Bulger, M. E. (2012). Measuring media literacy in a national context: challenges of definition, method and implementation. Medijske studije, 3 (6): 83-104.

7. Burroughs, S.; Brocato, K.; Hopper, P. F.; Sanders, A. (2009). Media Literacy: A Central Component of Democratic Citizenship. The Educational Forum, 73 (2): $154-167$.

8. Butcher, P. (2021). COVID-19 as a turning point in the fight against disinformation. Nat Electron, 4: 7-9.

9. Ciboci, L. (2018a). Vrjednovanje programa medijske kulture u medijskom opismenjivanju učenika osnovnih škola (doktorska disertacija). Zagreb: Filozofski fakultet Sveučilišta u Zagrebu.

10. Ciboci, L. (2018b). Medijska pismenost učenika osmih razreda u Zagrebu. Medijske studije, 9 (17): 23-46.

11. Ciboci, L. i Osmančević, L. (2015). Kompetentnost nastavnika hrvatskoga jezika za provođenje medijske kulture u hrvatskim osnovnim školama, u: Car, V.; Turčilo, L. i Matović, M. (Ur.). Medijska pismenost-preduvjet za odgovorne medije. Zbornik radova s 5. regionalne znanstvene konferencije Vjerodostojnost medija. Sarajevo: Fakultet političkih nauka Univerziteta u Sarajevu, 121-138.

12. Ciboci, L.; Ćosić Pregrad, I.; Kanižaj, I.; Potočnik, D.; Vinković, D. (2020). Nacionalno istraživanje o sigurnosti djece na internetu: HR Kids Online. http:// hrkids.online/prez/EUKidsOnlineHRfinal.pdf. (Pregledano 4. ožujka 2021.)

13. Danish Technological Institute, European Association for Viewers Interests (EAVI) (2011). Testing and Refining Criteria to Assess Media Literacy Levels in Europe - Final Report. Brisel: Europska komisija.

14. Direktiva 2007/65/EZ 
15. Duerager, A. and Livingstone, S. (2012). How can parents support children's internet safety?. London: EU Kids Online.

16. Eurobarometar (2018). Fake News and Disinformation Online. https://europa. eu/eurobarometer/surveys/detail/2183. (Pregledano 6. svibnja 2021.)

17. Europska komisija (2021). Suzbijanje dezinformacija o koronavirusu. https:// ec.europa.eu/info/live-work-travel-eu/coronavirus-response/fighting-disinformation/tackling-coronavirus-disinformation hr. (Pregledano 9. srpnja 2021.)

18. Faktograf.hr (2021). LIVE BLOG: Dezinformacije o koronavirusu. https://faktograf.hr/2021/07/09/live-blog-dezinformacije-o-koronavirusu-2/. Pregledano 11. srpnja 2021.

19. Kanižaj, I. i Car, V. (2015). Hrvatska: Nove prilike za sustavan pristup medijskoj pismenosti, u: Car, V.; Turčilo, L. i Matović, M. (Ur.). Medijska pismenost - preduvjet za odgovorne medije. Zbornik radova s 5 . regionalne znanstvene konferencije Vjerodostojnost medija. Sarajevo: Fakultet političkih nauka Univerziteta u Sarajevu, 19-38.

20. Livingstone, S.; Van Couvering, E. and Thumim, N. (2008). Converging Traditions of Research on Media and Information Literacies: Disciplinary, Critical and Methodological Issues. London: London School of Economics and Political Science. http://eprints.lse.ac.uk/23564/. (Pregledano 10. siječnja 2017.)

21. Macedo, D. and Steinberg, S. R. (Eds.) (2007). Media Literacy: A Reader. New York: Peter Lang.

22. Nielsen Company (2020). COVID-19: Tracking The Impact On Media Consumption. https:/www.nielsen.com/us/en/insights/article/2020/covid-19-tracking-the-impact-on-media-consumption/. (Pregledano 5. ožujka 2021.)

23. Odluka o donošenju kurikuluma za međupredmetnu temu Uporaba informacijske i komunikacijske tehnologije za osnovne i srednje škole u Republici Hrvatskoj, Narodne novine 7/2019.

24. Pérez-Tornero, J. M. (2014). Research on Existing Media Education Policies. Country Overviews. Barcelona: Gabinete de Comunicación y Educación. UAB. http://www.eumedus.com. (Pregledano 12. veljače 2017.)

25. Pérez-Tornero, J. M.; Paredes, O.; Giraldo, S.; Fernàndez, N. (2010). Indicators for assessing the critical understanding of media, in the European model of media literacy. https://santiagogiraldoluque.files.wordpress.com/2012/11/2-indicatorsfor-assessing-the-critical-understanding-of-media-in-the-european-model-ofmedia-literacy.pdf. (Pregledano 13. srpnja 2017.)

26. Potter, W. J. (2014). Media literacy. Thousand Oaks: Sage Publications.

27. Scheibe, C. L. (2004). A Deeper Sense of Literacy: Curriculum-Driven Approaches to Media Literacy in the K-12 Classroom. The American Behavioral Scientist, 48 (1): 60-68.

28. Scheibe, C. L. and Rogow, F. (2012). The Teacher's Guide to Media Literacy. Critical Thinking in a Multimedia World. Thousand Oaks, Calif: Corwin.

29. Silverblatt, A. (2001). Media Literacy: Keys to Interpreting Media Messages. Westport, Connecticut: Praeger. 
30. Statista (2020). In-home media consumption due to the coronavirus outbreak among internet users worldwide as of March 2020, by country. https://www.statista.com/statistics/1106498/home-media-consumption-coronavirus-worldwideby-country/. (Pregledano 3. ožujka 2021.)

31. Strategija obrazovanja, znanosti i tehnologije, Narodne novine 124/14.

32. Wardle, C. (2019). Information disorder: The techniques we saw in 2016 have evolved, First Draft. https://firstdraftnews.org/articles/information-disorder-thetechniques-we-saw-in-2016-have-evolved/. (Pregledano 8. svibnja 2021.) 


\title{
Critical Evaluation of Disinformation in the Media within the Formal Education System during the Coronavirus Pandemic
}

\author{
Lana Ciboci Perša
}

Edward Bernays University College, Zagreb, Croatia

e-mail: lana.ciboci@bernays.hr

\section{Tomislav Levak}

Academy of Arts and Culture, Department of Culture, Media and Management, Osijek, Croatia e-mail: tomo.levak@gmail.com

Adrian Beljo

Edward Bernays University College, Zagreb, Croatia

e-mail:adrian.beljo@bernays.hr

\begin{abstract}
Since the outbreak of the coronavirus pandemic, in addition to reliable and trustworthy information, plenty of disinformation about the virus, vaccination and its consequences have appeared in the media, especially on social networks. Exposure to the media during this crisis period pointed to the importance of having media competencies in order to select quality, reliable and trustworthy information. Namely, the critical evaluation of media content has become key to properly distinguishing trustworthy and reliable from untrustworthy and unreliable information. For adequate acquisition of media competencies, quality media education is important, which in Croatia, when it comes to the formal education system, is primarily conducted through Croatian language teaching, as well as also through various cross-curricular topics (Ciboci, 2018a.). Croatian language teachers and school librarians play a leading role in this process (Ciboci, 2018a.; Kanižaj and Car, 2015a.; Ciboci and Osmančević, 2015a.). In order to be able to educate the younger generations and encourage them to think critically about the media and media content, those who teach them must be media literate. The question arises as to how successful media education providers themselves are in recognizing disinformation in the media and how often, over the last year, have schools focused on these topics, since children as well as adults are exposed to plenty of disinformation about the coronavirus, which can greatly affect their attitudes and opinions on the overall pandemic. In this paper, analyzed using the survey method is to what extent school librarians recognize disinformation in the media, as well as how many activities in schools in the last year have been carried out with the aim of educating students about this important issue.
\end{abstract}

Key words: disinformation, critical evaluation, media education, media literacy, pandemic, coronavirus, librarians. 